\title{
Small Intestine Cancer pNO TNM Finding v8
}

National Cancer Institute

\section{Source}

National Cancer Institute. Small Intestine Cancer pNO TNM Finding v8. NCI Thesaurus. Code C133874.

Small intestine cancer with no metastasis to regional lymph nodes. (from AJCC 8th Ed.) 